UDC: 27-36:929 Konstantin Veliki

Борис Стојковски

Универзитет у Новом Саду

Филозофски факултет

Одсек за историју

stbs@ptt.rs
Оригиналан научни рад

примљено: 27. март 2013

прихваћено: 1. октобар 2013

\title{
ЖИТИЈЕ СВЕТОГ ЦАРА КОНСТАНТИНА У ЈЕРМЕНСКОМ СИНАКСАРУ ТЕР ИЗРАЕЛА*
}

Сажетак: Тер Израел, ерудита и црквено лице из Јерменије, почетка XIII столећа компиловао је, на основу ранијих извора, синаксар на јерменском језику за потребе цркве те хришћанске кавкаске земље. Уз неке касније допуне, овај синаксар представља прворазредни извор за црквену историју средњовековне Јерменије. У раду ће бити речи о житију Светог цара Константина Великог које је под 21. мајем, односно по старом јерменском календару 14. мареријем, похрањено у овом синаксару. Ово житије у овом раду биће преведено на српски језик уз неопходне коментаре и анализу самог описа живота цара Константина.

Кључне речи: цар Константин, јерменски синаксар, Тер Израел.

У време када се обележава 1.700 година од састанка Константина Великог и Лицинија у Милану (тзв. Милански едикт), вреди изнова проучавати и култ цара Константина Великог и његове мајке Јелене у целом хришћанском свету. Као што је добро познато, Константин I Велики прославља се као светац у свим православним црквама, заједно са својом мајком Јеленом. Дан када се славе јесте 21. мај по старом календару, односно 3. јун по новом календару. С друге стране, занимљиво је да Римокатоличка црква не признаје Константина као светитеља, иако је врло уважаван и поштован, док је његова мајка, Света царица Јелена, од најранијих векова слављена и веома поштована на западу као светитељка. У источним црквама, првог византијског и првог хришћанског цара, као и његову мајку, као светитеље прославља и Јерменска црква.

Управо је једно јерменско житије Светог цара Константина из синаксара Тера Израела тема нашег рада. Нажалост, до сада, иако посебно занимљиво, ово житије није преведено на наш језик, па преводом, као и коментарима, дајемо

\footnotetext{
* Текст је настао као фазни резултат рада на пројекту Војвођански простор у контексту европске историје (број 177002) Министарства просвете, науке и технолошког развоја Републике Србије и пројекту Средњовековна насеља на тлу Војводине. Историјски процеси и догађаји (бр. 114-4512216/2011), који финансира Покрајински секретаријат за науку Владе Аутономне Покрајине Војводине.
} 
скроман допринос приказу ширења Константиновог култа међу Јерменима, и уопште у древним хришћанским земљама.

Јерменија спада у најстарије хришћанске земље. Хришћанска вера је у Јерменију почела да продире из Сирије и Кападокије. Већ око 314. године, у време краља Тиридата III (298-330), Јерменија је постала хришћанска краљевина. Једна од најзаслужнијих личности за овако рани продор хришћанства и његово учвршћивање и ширење јесте краљев саветник и једна од најмаркантнијих личности јерменске историје - Свети Григорије Просветитељ. Он је, према традицији, покрстио краља, његову војску и јерменски народ. Већ око 400. године Месроп Маштоц је створио јерменски алфабет, а током V века почели су се компиловати и црквени, превасходно хагиографски списи. ${ }^{1}$ Већ у најранијем периоду по стварању сопственог писма црквени оци Јерменије су почели да састављају житија светих за сваки дан, за потребе црквених служби. Током средњег века многи значајни јерменски црквени великодостојници и писци су сакупљали житија светих мученика и сачињавали минеје и синаксаре. Треба истаћи име Григорија Магистра, који је, према традицији, потицао из фамилије самог Светог Григорија Просветитеља, а који је током XI столећа путовао Истоком и Западом и сакупљао хагиографске списе о светим мученицима, пророцима и апостолима. Он је превео на јерменски са грчког и бројне омилије, и начинио књигу која је названа Чарентир, односно Изабране беседе. Током XIII столећа највећи посао око сачињавања синаксара урадио је учени монах Тер Израел. Он је био један од ученика и сарадника Ховханеса Ванакана Вардапета (1170-1250), оснивача школе и библиотеке при манастиру Хоранашад. Месецослов који је он саставио зове се Јајсмавурк (у буквалном преводу: на данашњи дан) а који почиње првим даном Велике јерменске ере, која је, због разлике у календару, о чему ће нешто доцније бити речи, уместо 1. септембра почињала 11. августа, како почиње и синаксар. Последњу редакцију извршио је Григор Хлатеци у XV веку. Касније редакције су карактеристичне по томе што је додато доста житија јерменских светаца, посебно мученика који су пострадали у доба кад су јерменским краљевством управљали муслимански владари. ${ }^{2}$

У том јерменском синаксару налази се и житије Светог цара Константина. Оно се налази под датумом 14. марери, што одговара 21. мају, датуму под којим се у источним црквама и прослављају Свети цар Константин и његова мајка Јелена. Месец марери је десети месец старог јерменског календара. На овом месту укратко ћемо изнети неколико података о старом јерменском календару.

Стари јерменски календар је соларни календар, не зна за преступну годину и зато долази до померања његовог почетка у односу и на јулијански и на грегоријански календар. Прва година јерменске ере јесте 552. година, а званично овај календар је уведен 11. јула 584. године, за време католикоса Мовсеса II

\footnotetext{
${ }^{1}$ Питер Браун, Успон хришћанства на Западу. Тријумф и разноликост 200-1000. године, Београд 2010, 358-361.

${ }^{2}$ Le synaxaire arménien de Ter Israel I. mois de navasard (publié et traduit par G. Bayan), Patrologia Orientalis, tome 5, fascicule 3, $\mathrm{N}^{\circ}$ 23, Paris 1971, 5-9; Avedis Krikor Sanjian, Medieval Armenian Manuscripts at the University of California, Los Angeles, Berkeley and Los Angeles, 1998, 6; За Ховханеса Ванакана Вардапета упор. Vahan M. Kurkjian, A History of Armenia, New York 2008, 324-325.
} 
Еваргеција. Година се састоји од 12 месеци од по 30 дана, плус пет додатних дана (тзв. епагоменални дани) који не припадају ниједном месецу. Дани у месецу су углавном именовани, уместо нумерисани. Управо због овакве структуре календара први навасард у синаксару Тера Израела, који је предмет нашег рада, односно јерменска година, почиње 11. августа, а не 1. септембра, како је вероватно било испрва. Претпоставља се, међутим, да је први дан месеца навасарда, односно почетак јерменске године, одговарао почетку пролеће на северној хемисфери. Имена месеци у старом јерменском календару су: навасард, хор, сахм (сам), тре, калоц, арац, мехекани, арег, ахекани, марери, маргац и хротиц. Порекло имена месеци је вишеструко. Највише утицаја има из старогрузијских назива за месеце, али има доста и иранске етимологије, рецимо за први месец навасард, и још неке. Месец марери, који је у центру пажње нашег рада, име дугује баш арсакидском средњеиранском, односно парћанском дијалекту. Марери је генитив од речи *marear,

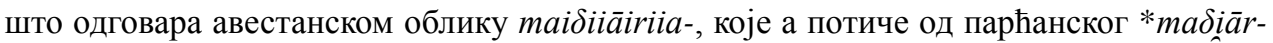
које означава пету годишњу прославу. ${ }^{3}$

Константиново житије у овом јерменском синаксару, као и читав синаксар, објављено је на основу два манускрипта. Први је париски, из фонда јерменских рукописа Националне библиотеке Ms. 180, са 339 фолија, на којиме је писано у две колоне. Овај месецослов Тера Израела потиче из 1316. године, односно 765. године јерменске ере, када је година почела 11. августа, односно том датуму одговара 1. навасард. Овај синаксар написао је писар Симеон, на Криму, за барона Сахаба, сина Ђантеровог. Свештеник Тиратур, син Кирјака, продао је овај спис 1394. године свештенику Гргуру, сину Тора, који је дописао неке белешке. Виде се два рукописа, две руке које су писале, а писано је јерменским болоргиром (курзив) XIV столећа. Други рукопис овог синаксара је званично издање јерменског синаксара Тера Израела, објављено у Цариграду 1834. године. Један примерак овог издања (иначе публикованог на јерменском језику) поседују боландисти и захваљујући њима је и публикован овај синаксар. ${ }^{4}$

Комбиновањем ова два рукописа др Г. Бајан публиковао је критичко издање целог синаксара Тера Израела са преводом на француски језик, а у оквиру едиције Patrologia Orientalis. У петом тому који је изашао 1910. године Бајан је објавио синаксар за месец марери у коме се налази и житије цара Константина Великог, о коме ће бити речи. Репринти овог издања уследили су најпре 1971, а затим и 2003. године. Ово издање смо и ми користили у овом раду. У наставку следи превод овог житија на српски језик. Затим следи поглавље са превасходно историјским коментарима података који су донети у овом житију првог хришћанског цара.

\footnotetext{
${ }^{3}$ O јерменском календару упор. неколико класичних радова: V. Bănăţeanu, Le calendrier arménien et les anciens noms des mois, Studia et Acta Orientalia 10, 1980, 33-46; Jost Gippert, Old Armenian and Caucasian Calendar Systems [I], Annual of Armenian Linguistics 8, 1987, 63-72; Исти, Old Armenian and Caucasian Calendar Systems 2. Armenian hori and sahmi, The Annual of The Society for The Study of Caucasia 1, 1989, $3-12$.

${ }^{4}$ Le synaxaire arménien de Ter Israel I. mois de navasard, 5.
} 


\title{
ПРЕВОД ЖИТИЈА СВЕТОГ ЦАРА КОНСТАНТИНА И ЦАРИЦЕ ЈЕЛЕНЕ:
}

\author{
14. марери \\ Празник цара Константина и његове мајке Јелене који су били први \\ хришћански цареви ${ }^{5}$
}

Константин, римски цар, испрва је био паганин, син Констанција названог Хлор. Ја ћу испричати како је био син Констанција Хлора према списима Светог мученика Евсигнија.

У дане (када је владао) цар Констанције, војници су пролазили кроз град Хеленополис и застали су код жене по имену Јелена која је држала крчму. Њен млади син беше подигнут на коња једног од војника. Војник му је дао крчаг и скинуо га с коња. Дечак је почео да плаче. Јелена је рекла: „Не ударај га, јер то је дете цара!“ Војници су је упитали како то може бити. Она им одговори: „Кад се цар Констанције враћао из Персије, стао је код мене, пожелео ме је због моје лепоте и спавао са мном. Затруднела сам с њим и донела сам на свет дете“. Она им показа поклоне које је добила од цара. Војници су јој честитали, а она им је дала (цареве) дарове, како би му их могли показати.

Војници отидоше за Рим. Како Констанције није имао деце, преко префекта и управитеља, тражио је неко лепо дете да га усвоји и учини наследником свога царства. Војници су обавестили цара о Јелени и њеном детету и показали му дарове.

Када их је он (цар) видео, признао је и присетио се дана кад је преспавао код Јелене; одмах је послао војнике са великом свитом и царским коњима опточеним златом, који су довели дете у Рим. Чим га је цар видео, испуни се сав радошћу, загрли дечака и обдари га влашћу и моћи трибуна и пошаље га у Византију (Визант), дајући му трупе за ратовање са варварима. Он (дете) отиде, победи непријатеље и врати се у Рим после једног великог тријумфа; (Констанције) га крунисао и уздигао такође за цара.

Учинио је да у Рим дође и његова мајка Јелена, крунисао ју је и учинио царицом Римљана; сви прваци и народ се поклонише пред мајком и дететом.

После смрти Констанција владао је његов син Константин, рођен од Јелене. Две стотине деведесет осам година је протекло од рођења Христовог до доласка Константина на власт.

Када је (Константин) видео на небу визију Часног крста, напустио је Рим, отишао у Визант, одатле у Никомедију, борио се са Ликијаном (Лицинијем) и победио га. Што се тиче његове болести од лепре, она је описана у житију папе Силвестера, 2. јануара.

Константин, пошто је уочио изванредну позицију Византиона, подигао је град, ојачао зидине, улепшао поплочане улице и засведене лукове, и крају граду дао своје име - Константинопољ. Раскошно је посветио град 21. маја. Послао је своју мајку у Јерусалим, која је тамо открила Часни крст, укопан у земљу од стране Јевреја. Пренео је царство из Рима у Константинопољ.

А кад се појавио Арије, богохулник на Свете Тројицу, велики Константин је сазвао три стотине и осамнаест епископа у граду Никеји у Витинији; и двадесете године његове владавине одржан је Сабор у Никеји, где је анатемисана и искорењена зла шизма Аријева. (Константин) замоли све епископе да дођу у Константинопољ и да га благослове великим благословима.

Три стотине осамнаест Христових свештенослужитеља попеше се на

\footnotetext{
${ }^{5}$ Le synaxaire arménien de Ter Israel X mois de maréri (publié et traduit par G. Bayan), Patrologia Orientalis, tome XXI, fascicule 4, Paris 1930 (репринт Turnhout, 1994), 482-486.
} 
зидине града, ходајући укруг са молитвама и благословима: молили су Бога да никад не дозволи да (град) падне у руке неверника. Пошто су поздравили цара и Светог Митрофана, епископа Константинопоља, вратише се сваки на своју столицу.

Константин је био подигао у средини града велики стуб, на чијем се врху налазила колосална позлаћена статуа од бронзе, која је донета из Рима и која се звала Анитеј (Анитеос). Ставио је Анитеју у руку крст на коме је урезао: „Теби Христе Боже посвећујем овај мој град“. У подножју је ставио дванаест корпи и напунио их хлебом, након чега је мноштво јело, и било су задовољени од Христа. Поделио је (Константин) Часни крст Спаситељев на два дела: једну половину дао је цркви Васкрсења Христовог у Јерусалиму, а другу је половину дао граду Константинопољу.

Константин је побожно владао тридесет и две године после свог крштења и преставио се у вечни свет 21. маја, 14. марерија, оставивши као наслеђе своја три сина: Констанција, Констанса и Константина. Сахрањен је у гробу своје мајке у Константинопољу.

Од рођења Христовог до владавине Константинове и Сабора у Никеји прошло је две стотине деведесет и осам година.

\section{Коментари:}

Оно што је свакако најважније рећи јесте то да је ово житије по структури веома специфично. Видимо да оснивање Цариграда заузима велики његов део, док се, рецимо, готово уопште не расправља о Константиновом преобраћењу у хришћанство. Штавише, Константиново преобраћење у хришћанство се налази у овом синаксару, али у месецу калоцу, односно 2. јануара на празник папе Силвестера. Милански едикт, тј. састанак Константина и Лицинија у Милану, такође се не наводи. Напоменимо и то да о Константину и бројним питањима из његовог живота и владавине постоје читаве библиотеке, стога смо у коментарима дали само упут на основну литературу која обрађује неко питање и на неколико кључних извора, јер је преглед извора који спомињу Константина Великог непресушан и неисцрпан.

Сам почетак овог житија је занимљив, јер писац помиње да ће причу о Константиновом пореклу испричати на основу списа Светог мученика Евсигнија. Приређивач овог синаксара Бајан у напомени самог житија наводи да су писци житија помешали Евсигнија са Јевсевијем из Кесарије, Константиновим биографом. ${ }^{6}$ Свакако да ово није немогуће, али, ако се упореде садржаји, јасно је да је и пасија Светог мученика Евсигнија можда била извор за ово житије, или макар позната писцу. Реч је о пасији о војнику Евсигнију који је цару Константину објаснио знак крста и натпис „У овом знаку побеђујеш на небу“. И његово име, које значи добар знак, обично се доводи у везу са евангелизацијом, односно ширењем добре вести крста на небу. Грчка верзија његове пасије представља Евсигнија као жртву прогона Јулијана Апостате. Према истом корпусу хагиографских списа, Евсигније је пострадао у Антиохији. Ова грчка верзија пасије Светог Евсигнија такође доноси и причу о томе како је Јелену цар Констанције Хлор извео из развратног живота, а

\footnotetext{
${ }^{6}$ Le synaxaire arménien de Ter Israel X mois de maréri, 482, нап. 1.
} 
њиховом сину (Константину, наравно) је Бог обећао да ће бити у пурпуру, односно да ће постати цар. ${ }^{7}$ Управо ова легенда и следи у наставку Константиновог житија у јерменском синаксару. Дакле, вероватније је да је пасија, односно житије Евсигнијево било примаран извор за почетак овог Константиновог житија, него Јевсевије, и да Тер Израел, односно редактори његовог синаксара, нису погрешили.

Легенда коју приређивачи јерменског синаксара доносе у наставку Константиновог житија позната је још од седмог столећа, а према неким стручњацима и од раније. Према тој легенди, отац Јеленин, иначе власник крчме, понудио је цару услуге своје ћерке а она је у знак захвалности од Констанција Хлора добила пурпурни огртач. Констанције је исте ноћи уснио чудан сан о сунцу које се рађа на западу. На одласку је рекао власнику крчме да добро чува ћерку и дете које ће носити. Затим се вратио у Рим. Наставак ове средњовековне легенде је уклопљен у Константиново јерменско житије, о војницима који се враћају из похода и стају у каснији Хеленополис, односно вероватно Дрепанум. Препознају дете по пурпурном огртачу (вероватно су то дарови који се наводе у месецослову) и онда мајка и син одлазе у Рим. ${ }^{8}$

На овом месту нећемо улазити у детаље Константиновог раног живота. Поменућемо да Констанције Хлор није владао у Риму, нити је сам Константин Велики у Риму проглашен за августа, већ се то, као што је познато, десило по смрти његовог оца 306. године у Ебуракуму, данашњем Јорку, након заједничког рата са Пиктима. Зна се да је Константин у ратовима пре него је постао цезар, па и пре него што је прокламован за августа, био уз Диоклецијана у Палестини, Египту (297), Месопотамији (298-299), а 299. године је војевао против Сармата на Дунаву. ${ }^{9}$ Истаћи ћемо и општепознату чињеницу да престоница Констанција Хлора није био Рим, док је помен Византиона очигледно грешка. Евентуално је могла доћи у обзир Никомедија.

Што се поглавља о сукобу са Лицинијем тиче, вреди поменути следеће. Свакако да се овде мисли на период после битке на Милвиском мосту (кад се и десила Константинова визија). Хронологија аутора синаксара није најпрецизнија, као ни Константинов итинерар. После победе над Максенцијем, 313. Константин и Лициније се срећу у Милану. Уследила је прво битка код Цибале, у октобру 314. године. Њихов сукоб избија наново 316. године, док наредне године потписују примирје, односно споразум, али до сукоба опет долазили. Коначно, одсудна битка се десила 3. јула 324. године код Хадријанопоља. Потом се Лициније склонио у Визант, а онда је дошло до поморске битке, да би на концу ових сукоба Константин

\footnotetext{
${ }^{7}$ The Coptic Encyclopedia volume IV, editor-in-chief Aziz S. Atiya, New York 1991, 1071-1072 (Michel van Esbroeck) са литературом; за грчке пасије и њихова места публиковања упор. и François Halkin, Bibliotheca hagiographica Graeca, Bruxelles $1957^{3}, 200$.

${ }^{8}$ О овој легенди вид. Jan Willem Drijvers, Helena Augusta. The Mother of Constantine the Great and the Legend of Her Finding the True Cross, Leiden - New York - København - Köln 1992, 16-17, нап. $42-43$ са додатном литературом.

${ }^{9}$ Основне податке о томе даје Јевсевије, упор. Eusebius, VC I, 19; од литературе вид. Jakob Burkhart, Doba Konstantina Velikog, Sremski Karlovci - Novi Sad 2006, 349-350; Bertrand Lançon, Tiphaine Moreau, Constantin. Un Auguste chrétien, Paris 2012, 30-34.
} 
опсео Лицинија у Никомедији и овај му се предао. Лициније је затим изгнан у егзил у Солун, где је и погубљен. ${ }^{10}$ Видимо, дакле, да постоје непрецизности превасходно у Константиновом итинерару и следу догађаја везаних за његов сукоб са Лицинијем, али да су подаци у суштини тачни и одговарају историјској истини.

Сасвим је другачије у вези са последњим податком. Наиме, наводно Константиново излечење од лепре од стране папе Силвестера налази се чак и у фалсификованој Константиновој даровници. Према овом лажном документу, због наводног излечења од лепре, Константин Велики је папи даровао сву световну и духовну власт у Италији и на Западу. Доиста, та легенда, опдносно пролегомена за оно што пише у даровници је врло подробно описана и уистом овом синаксару, али под 25. калоцем, односно 2. јануаром у врло опсежном и детаљном житију самог папе Силвестера. Читаво једно посебно поглавље овог житија посвећено је легенди о томе како је папа Силвестер излечио Константина од лепре. Реч је готово о потпуно преузетом тексту из легенде Actus Sylvestri која је почела да се развија још у IV столећу, а коју су преузимали током средњег века и Часни Беда у Енглеској, али и Теофан, Јован Малала и Кедрен у Византији. ${ }^{11}$ Очигледно је ова легенда била позната и у Јерменији у позном средњем веку и нашла чак место у месецослову и житију Константиновом. Прича о папи Силвестеру је сачувана у грчким и сиријским издањима, па је готово извесно тако дошла и до Јермена. Само давање власти папи није описано у јерменском синаксару, али је несумњиво реч о чину излечења који се помиње и у Даровници. ${ }^{12}$

Изградњи Цариграда посвећен је велики део Константиновог житија. Аутор преузима од Зосиме да је Константин био заведен положајем града. Први хришћански цар доиста јесте подигао зидине, о чијем положају данас мало знамо. Док је Нови Рим изграђиван, пренето је много стубова, и мермера. Посебно је велики број колонада био у улици Меса која је водила до форума. У јерменском месецослову је релативно верно, односно у складу са познатим изворима, описано грађење Константиновог форума. Заиста су у подножју стуба, према предању, похрањене корпе са хлебом којим је Христос нахранио пет хиљада људи, као и бројне друге реликвије, попут Нојеве секире којом је исклесао барку и реликвије светаца. На врху се додуше налазила Аполонова статуа, пренета из Хеленопоља у Фригији, а касније је уместо Аполонове главе стављена глава цара Константина Великог. Натпис, који помиње редактор јерменског месецослова, није се налазио на крсту који је статуа држала у руци него у основи самог стуба. Што се посвећења тиче, оно је обављено и по паганском и по хришћанском ритуалу 11. маја 330.

\footnotetext{
${ }^{10}$ J. Burkhart, Нав. дело, 325-330; Hans A. Pohlsander, The Emperor Constantine, London - New York 2004, 40-45; Радивој Радић, Константин Велики. Надмоћ хришћанства, Београд 2010, 100-104, 108-110; В. Lançon, T. Moreau, Op. cit., 36-37.

${ }^{11}$ O овој теми постоји обимна библиографија, упор. најновије дело са пописом кључне литературе на ову тему: Athanasius Kapsalis, The false donation of Constantine, Свети цар Константин и хришћанство (ур. Драгиша Бојовић), Ниш 2013, 91-107. Преглед и западних и византијских извора о овој теми даје Н. А. Pohlsander, Op. cit., 26-29.

${ }^{12}$ Le synaxaire arménien de Ter Israel V mois de kalotz (publié et traduit par G. Bayan), Patrologia Orientalis, tome XVIII, fascicule 1, Paris, 1924 (репринт Turnhout 1974), 169-173.
} 
године, свечаности су трајале четрдесет дана, дакле после Сабора у Никеји, тако да је опис посвећења у овом Константиновом житију плод легенде, о којој ћемо нешто рећи у наредним одељцима нашег прилога. ${ }^{13}$

Као што смо видели, само је у једној узгредној реченици споменут одлазак Јеленин у Јерусалим и њен проналазак Часног крста на коме је Христос распет. ${ }^{14}$ Много више пажње је посвећено Првом васељенском сабору, одржаном у Никеји 325. године. Традиција везује број од 318 учесника сабора (вероватно из Пост. 14:14) за спомен на 318 Аврамових робова, али тачан број учесника није познат, нити га дају извори; подаци су различити и противречни, зна се да је број био виши од две стотине. На сабору је доиста проклета Аријева јерес, међутим, како је овај сабор претходио освећењу и уопште изградњи Константинопоља, цар их није могао позвати у нову престоницу. Јесте их позвао 25. јула, на свечаност у Никомедију, у своју царску палату, на свој dies Imperii. Очигледно је дошло до мешања резиденција у које су епископи позвани од стране цара. Осим тога, у овом месецослову наилазимо и на помен Светог Митрофана, епископа града Византа у време Константина и Првог васељенског сабора у Никеји. Митрофан се, по црквеној традицији, често назива првим патријархом Цариграда, што не одговара историјској истини. Он јесте био епископ града Византа и послао свог хороепископа на Сабор у Никеју, али није посветио нову престоницу (умро је 325), нити се, макар следствено изворима којима располажемо, посвећење града одвијало сасвим по јерменском синаксару Тера Израела. ${ }^{15}$

Константинова улога на Никејском сабору није промакла ни другим јерменским изворима. У једном од најважнијих извора за средњовековну јерменску историју, али и за односе Византије и Јерменије, у Историји која се приписује Себеосу, насталој у VII столећу, Константин се назива богољубивим краљем, блаженим, а чак се наводи да се поклонио и тражио благослов од Светог Григорија Просветитеља. И Себеос исказује велико поштовање према Константину, пишући како је под његовом управом Никејски сабор победио све јереси и дао замах ширењу праве вере. ${ }^{16}$

\footnotetext{
${ }^{13}$ Од извора који спомињу изградњу града вид. Philostorg. HE, II, 9; Zos. HN, II, 30-32; Eusebius, VC III, 48; што се литературе тиче вид. Драган Вукић, Цариград око васељене, Београд 2009, 24, 318-319, 446; Стивен Мичел, Историја позног Римског иарства 284-641. Преображај античког света, Београд 2010, 316-318; B. Lançon, T. Moreau, Op. cit., 89-91. Упор. о овој теми и коментаре на Јевсевијев Живот Константинов: Eusebius, Life of Constantine (introduction, translation and commentary by Averil Cameron and Stuart G. Hall), Oxford 1999, 297-299.

${ }^{14}$ Иако о томе постоји бројна литература, овде дајемо само најбитније и вероватно најпотпуније дело које се бави овом тематиком: J. W. Drijvers, Op. cit., 79-81, 95-180 са екстензивном библиографијом.

${ }^{15}$ О самом Сабору и броју учесника вид. Антон Карташов, Васељенски сабори, Београд 2009, 29-37, о броју учесника на 31; врло леп опис сабора вид. у: Р. Радић, Нав. дело, 129-139; A. Pohlsander, Op. cit., 5053. Што се легенде о Светом Митрофану тиче, упор. Propylaem ad Acta sanctorum novembris. Synaxarium ecclesiae Constantinopolitanae (opera et studio Hypolite Delehaye), Bruxellis 1902, 727-730. Ова прича о епископима са Првог васељенског сабора који долазе к Митрофану опстала је у црквеној литургијској традицији, а спомиње је код нас и епископ Николај, Охридски пролог, Линц 2001, 350-351. Свети Митрофан се слави 4/17. јуна.

${ }^{16}$ The Armenian History attributed to Sebeos (translated, with notes, by R. W. Thomson, historical Commentary by J. Howard-Johnston, Assistance from T. Greenwood), Liverpool 1999, 122-126.
} 
Евидентно је да се на крају самог житија наводи хронолошка грешка, из више разлога. Углавном је познато да се Константин крстио на самрти. Знамо, такође, да се Сабор у Никеји одржао 325. године по Христовом рођењу, што је озбиљна хрнолошка омашка. Његови наследници су заиста била његова три сина, који ће се међусобно озбиљно сукобљавати. Што се места Константиновог погреба тиче, он је сахрањен у Цркви Светих апостола, маузолеју који је подигао у Новом Рим - Константинопољу. ${ }^{17} \mathrm{C}$ друге стране, мајку је сахранио у порфирном саркофагу у маузолеју близу Цркве Светог Марцелина и Петра у Риму, ${ }^{18}$ тако да податак везан за смрт првог хришћанског императора не можемо прихватити као тачан.

Као општи закључак, можемо истаћи да је житије Светог цара Константина и царице Јелен (која се додуше врло мало помиње) у јерменском синаксару Тера Израела занимљив хагиографски приказ живота првог хришћанског цара. Извори које су редактори месецослова користили су бројни, укључују и многе легенде и црквене традиције које су опстале током столећа. Многи од тих извора, попут пасије Светог мученика Евсигнија, нису често коришћени у Константиновим хагиографским списима. Приметан је веома мали утицај Јевсевија и његовог дела. Због своје специфичне структуре, као и занимљивих извора, ово житије је вредан и занимљив извор за хагиографију и историографију јерменског средњовековља и култ Светог цара Константина у најдревнијој хришћанској земљи.

Извори и литература:

Извори:

The Armenian History attributed to Sebeos (translated, with notes, by R. W. Thomson, historical Commentary by J. Howard-Johnston, Assistance from T. Greenwood), Liverpool 1999.

Епископ Николај, Охридски пролог, Линц 2001.

Eusebius, Life of Constantine (introduction, translation and commentary by Averil Cameron and Stuart G. Hall), Oxford, 1999.

Zosime, Histoire Nouvelle (édition et traduction François Paschoud), 3 tomes en 5 volumes, Paris 1971-1989.

Le synaxaire arménien de Ter Israel I. mois de navasard (publié et traduit par G. Bayan), Patrologia Orientalis, tome 5, fascicule 3, $\mathrm{N}^{\circ} 23$, Paris 1971.

Le synaxaire arménien de Ter Israel X mois de maréri (publié et traduit par G. Bayan), Patrologia Orientalis, tome XXI, fascicule 4, Paris 1930 (репринт Turnhout, 1994).

Le synaxaire arménien de Ter Israel V mois de kalotz (publié et traduit par G. Bayan), Patrologia Orientalis, tome XVIII, fascicule 1, Paris 1924 (репринт Turnhout 1974).

Philostorgius, Church History (editor and translator R. Philip, S. J. Amidon), Atlanta 2007.

Propylaem ad Acta sanctorum novembris. Synaxarium ecclesiae Constantinopolitanae (opera et studio Hypolite Delehaye), Bruxellis 1902.

\footnotetext{
${ }^{17}$ Euseb VC, IV, 68-73.

${ }^{18}$ J. W. Drijvers, Op. cit., 73-76.
} 


\section{Литература:}

Bănăţeanu, V., Le calendrier arménien et les anciens noms des mois, Studia et Acta Orientalia 10, 1980, 33-46.

Браун, Питер, Успон хришћанства на Западу. Тријумф и разноликост 200-1000. године, Београд 2010.

Burkhart, Jakob, Doba Konstantina Velikog, Sremski Karlovci - Novi Sad 2006.

Вукић, Драган, Цариград око васељене, Београд 2009.

Gippert, Jost, Old Armenian and Caucasian Calendar Systems [I], Annual of Armenian Linguistics, 8, 1987, 63-72.

Gippert, Jost, Old Armenian and Caucasian Calendar Systems 2. Armenian hori and sahmi, The Annual of The Society for The Study of Caucasia 1, 1989, 3-12.

Drijvers, Jan Willem, Helena Augusta. The Mother of Constantine the Great and the Legend of Her Finding the True Cross, Leiden - New York - København - Köln 1992.

Kapsalis, Athanasius, The false donation of Constantine, Свети цар Константин и хришћанство (ур. Драгиша Бојовић), Ниш 2013, 91-107.

Карташов, Антон, Васељенски сабори, Београд 2009.

Kurkjian, Vahan M, A History of Armenia, New York 2008.

Lançon, Bertrand, Moreau, Tiphaine, Constantin. Un Auguste chrétien, Paris 2012.

Мичел, Стивен, Историја позног Римског царства 284-641. Преображај античког света, Београд, 2010.

Pohlsander, Hans A., The Emperor Constantine, London - New York 2004.

Радић, Радивој, Константин Велики. Надмоћ хришћанства, Београд 2010.

Sanjian, Avedis Krikor, Medieval Armenian Manuscripts at the University of California, Los Angeles, Berkeley and Los Angeles, 1998.

Halkin, François, Bibliotheca hagiographica Graeca, Bruxelles $1957^{3}$.

The Coptic Encyclopedia volume IV (editor-in-chief Aziz S. Atiya), New York 1991. 


\title{
BORIS STOJKOVSKI
}

\section{THE LIFE OF SAINT CONSTANTINE THE GREAT IN ARMENIAN SYNAXARION OF TER ISRAEL}

\begin{abstract}
Summary
Ter Israel, erudite and Armenian Church father from the beginning of the 13th century compiled, based on some earlier sources, synaxarion in the Armenian language for the needs of the Church of that Caucasian country. With some later additions, this synaxarion represents first class source for the church history of medieval Armenia. In the paper the Life of Saint Constantine the great and Empress Helen was treated, which can be found in this synaxarion under 21st of May, or 14th mareri according to the old Armenian calendar. This Life is for the first time translated into Serbian language with necessary comments and the analysis of the description of Emperor Constantine's life. The author has given special stress on the sources used for writing this hagiographic work. One interesting thing is pointed out, namely the usage of passion of Saint Eusignius, but what is also notable, is not quite wide use of Life of Constantine by Eusebius, which is primary source for all hagiographic works about the first Christian emperor. Constantine's conversion to Christianity provided in this Armenian menologion is described on the basis of Life of Saint Sylvester, which provides rather specific and most probably completely inaccurate data on Constantine's conversion to Christian faith. There is a lot of Church tradition present in the writing, as well as Byzantine legends, for example the one on Saint Mitrophanos, the bishop of the city of Byzantion and the First Ecumenical council. The editors of the writing dedicated great attention to the emergence of Constantinople, which partially is in accordance with other historical sources.

Constantine's mother, Empress Helen, is just briefly mentioned. Editors of the Armenian synaxarion mention only her origin, by using the already mentioned passion of Saint Eusignius. A part that, in a very short sentence her trip to Jerusalem and her alleged finding of the True Cross is described. The last data on her is in context of Constantine's funeral. According to the authors of this Life, Emperor is buried alongside his mother Helen, which is not in accordance with historical sources.

Even though there are certain imprecise data, even inaccuracies, this work is especially interested as a contribution to the cult of Saint Emperor Constantine and Empress Helen in Armenia, one of the most ancient Christian countries and nations.
\end{abstract}

Keywords: Emperor Constantine, Armenian Synaxarion, Ter Israel. 